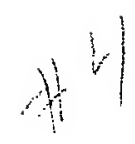

No. X.

A PAPER

ON THE IMPORTANCE OF ENCOURAGING

TIE

\title{
IRISH FISHERIES
}

AS A $\mathrm{K}$

INDUSTRIAL RESOURCE,

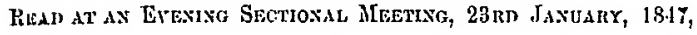

By J. C. DEANE, EsQ., M.R.I. $\Lambda$.

Is oeeupying the attention of a Society for the promotion of national industry, I might at any time ealeulate on your indulgenee towards sueh suggestions as I might be enabled to offer for the derelopment of an important branch of our industrial resourees; but at a period like the present, when a want of food presses upon all elasses of the eommnnity, I mayr perhaps elaim a more earnest and farourable eonsideration in subunitting to your notiee some facts regarding those great stores of food which Providenee has plaeed around our shores, aetually within our reach, unused and unavailable,-I mean the fisheries. They have been from time immemorial a souree of supply, sometimes to ourselves, at other times to neighbouring nations, but never to the extent to whieh they might have been eultivated.

In our earlier reeords eoneeruing the state of the Irish fisheries, I find that a Statute was framed in the reign of Elizabeth, prohibiting foreign vessels from fishing in our seas without a lieense; and in the reign of Mary, the King of Spain was allowed by her Majesty to fish on the eoasts of Ireland, for whieh he paid $£ 3000$ per annum in to the Irish exehequer. In Charles the First's reign the Duteh paid $£ 30,000$ for liberty to fish during the summer of 1635 in the British seas; and, no doubt, drew large supplies from the rieh treasures of our Irish seas. Indeed it is likely that they fished with more sueeess on the eoasts of our island than on those of England and Seotland, for during the prevalenee of the wars of that period, there was less liability of their being interrupted in their pursuit. It is 
well agreed, however, by all those who have written upon the subjeet, that from the British and Irish seas the Hollanders drew their wealth and greatness; "not," says a learned writer, "that they are to be quarrelled with, but rather eommended for their industry, and we justly reproaehed for our sloth and negligenee in not partaling of sueh a blessing whieh Providenee has thrown at our doors." In 1650 Sweden also sent one hundred vessels to fish on our banks, having been permitted as a favour so to do, so little did we then know of the value of our fisheries. The deplorable eondition of the British fisheries in the reign of James the First ealled forth the able advoeaey of no less 'a personage than Sir Walter Raleigh, who addressed His Majesty on the subjeet, and in dwelling on the inestimable riehes of the British seas, says: "That our" sea and land eommodities emieh and strengthen other eountries against our own ; and in the great sea business of fishing the Hollanders employ near 20,000 ships on the eoast of England, Ireland, and Seotland, and are enabled, and do build one thousand ships and vessels yearly, having not one timber-tree growing in their eountry, nor home-bred eommodities to load 100 ships, and yet they have 20,000 ships and vessets, and all employed. That by twenty busses are set on work 8000 persons by sea and land, and an inerease of 10,000 mariners. That the mighty huge fishing that ever could be heard of in the world is on the coasts of England, Seotland, and Ireland; but the great fishery or praetiee thereof is in the Low Commines, and other petty states, wherewith they serve themselves and all Christendom." Of the faet, that the riehes of the nation eould be materially inereased by a sueeessful proseention of the fisheries, Sir Walter appeared to be fully sensible, and urged the neeessity of advaneing and eherishing the interests of the fishermen in the following eogent reasons: "First," said he, "they are useful for taking God's blessing out of the sea ; seeondly, for setting the people on work; thirdly, for making plenty and eleapness in the reahn; fourthly, for inereasing ships to make the land powerfid; fifthly, for a eertain nursery for breeding and increasing mariner's; sixthly, for making employment for all sorts of people, as blind, lame, and others, by sea and land, from ten or twelve years and upwards; seventhly, for emiehing your Majesty's eoffers by merehandize returned from other countries for fish and herrings; eighthly, for the inerease and enabling of merehants, which now droop, and daily deeay." Sir William Temple, in a letter addressed to Lord Essex, in 1673 , says that the fisheries of Ireland " might prove a mine under water, as rieh as any under ground;" and he went so 


\section{lxiii}

fal" as to propose that no one "should be eligible to sit in the House of Commons, or be entitled to the eommission of the penee, unless he had taken a praetieal part in the management of that brameh of our industry." Of the poliey of this suggestion I leave you to judge. It is, lowever, eertain, from the opinions at lenst of those who thonght upon the subjeet in those times, that the value of the fisheries was unappreeiated, and deplorably negleeted by our eountry, to the immeasurable wealth of others, and to our own shame.

While the minds of men of speeulntive genius were thus direeted to the subjeet, our Legislature, as might naturally be expeeted. was not inattentive to the eneouragement and extension of the Irish fisheries, as objeets of importanee in a national and eommereial point of view; and before $I$ proeeed to eonsider their existing state, I shall very briefly glanee at the progress whieh they have made through the medium of legislative assistanee.

In the reign of George II. (the earliest Statute whieh I think it neeessary to refer to) an Aet was passed for the eneouragement of the eoast fisheries; and about this time Mr. Doyle, an hydrographer, diseovered a most valuable and produetive fishing-bank off Waterford, where he fished with the greatest sueeess. He named the bank after his boat, "the Nymph," and being then about to publish a ehart of the larbour of - Waterford, he macle sketehes of the various headlands, with their bearings from the bank, whieh he engraved for the ehart. Mr. Doyle made eertain proposals to supply the English markets with fresh fish, but they were not then put into exeention.

In the third year of the reign of George III. the system of bounties was first adopted by the Irish Parliament, and twenty shillings per ton was grinted on all deep-sea fish ; but a subsequent Statute (the 25 Geo. III.) limited this bounty to " fish for euring, and the eonsequenee of this ehange was great distress among the fishermen ; and on the 19th March, 1789, a petition was reeeived from the Skerries fishermen (the prineipal body), eomplaining of having been rumed by fishing for the bomty on the North-west eoast under the new law, and praying for aid to pay their debts, and earry on the fishing for the Dublin market." The 41 George III. granted the large sum of $£ 30,000$ for bounties for supplying fresh fish to the English markets, whieh indueed anotler attempt to be made to fish " the Nyruph Bank," Mr. Frazer being seleeted to earry out the experiment, the Irish Govermment eoming forward

* Commentaries on Ireland. Second edition.

$\ln 2$ 
most liberally in its aid. It appears, however, that the projeet was sacrificed to party purposes. In the year 1803 the Mariue Society offered their assistance to the Nymph Bank Company, which offer was rejected; and the Society, determining to fish on their own account, sought an Act of Incorporation, bnt not having succeeded in obtaining it, their intention was frustrated. Mr. Frazer is reported to have eontinued to fish upon the Bauk with some fair siccess, bnt in the year 1804 the Company was dissolved. Various enactments, fiom the year 1776, extend. ing over a period of ten years, were passed for the encoruragement of the Irish fisheries. In the year 1786 the bounty was raised to $4 s$. per barrel, and prcminms mere offered for the four greatest quantities of herrings taken between the 1st of January and December the 31st of that year'; and after this several Statutes continuing the old bounties were passed, mutil the year 1819, when the Irish Fishery Boasd was formed.

In that year a bomty of $£ 210 s$. per ton was granted to the owner or person chartering or lining any vessel of fifteen tons or upwards, for fishing and curing fish, but not to be paid for any greater number of tons than sixty. There was also a bounty on whale-oil and whalebone. In 1820 the tonnage bounty was increased to three shillings per ton; and in $182 \underline{4}$, by the 5 Geo. IV. c. 64 , that on prodnetion was redueed to fonr shillings per barrel for herrings, to be annually redneed one shilling per barrel, and to eease finally in 1829 ; and the tomnage bounty, by an amnual abatement of five shillings per ton, was also direeted to be discontimued at the same time. The system continned, however, to operate till April, 1830.

Grants for repairing and construeting piers and harbours, and for repairing poor fishermen's boats, were distributed from the year 1819 to $1830, £ 5000$ per annum being placed at the disposal of the Commissioners for that purpose. Loans to fishermen, part of an accumulated fund, was set apart by the Board to assist in repairing the boats and fumishing genr; but great diffoulty was experieneed in administering the system to advalltage: frauds to a very great extent were praetised, and the loans were diseontinned. The residue of the grants vested in the Fishery Board was, after the dissolution of that body, first entrusted to the Board of Inland Navigation, and shortly afterwards to the Board of Works. In the year 1835 a Commission was directed to inquire into the state of the Irisl fisheries; and in 1836 they fumished a most valuable Report, which eontains an immense mass of information, being the evidence and experience of all those who were then engaged in the fisheries, or likely to know much abont them. In the year 1842 an 
Aet was passed, 5 \& 6 Viet. e. 106, which provided for the registry of fishing vessels, under whiel, (with a more reeent Statute (the Piers and Harbour's' Aets), whieh I shall have oceasion to refer to before I eonelnde), our eoast fisheries are at present managed.

I believe this shortly brings before you the legislation whieh was provided for the eneourngement and promotion of our fisheries. The most inportant of those enactneents was that whieh eneonraged the building of vessels for the fishing trade, by giving bounties on produetion and tonnage. During its continuance there can be no cloubt that a stimulus was given to the energies of the fishermen; but, upon the other hand, it gave rise to a perpetration of frands and evasions whieh were by no meaus ealenlated to forward the true interests of the trade, or improve the moral eondition of those engaged in its pursuit. It is unneeessary for ne to diseuss the various opinions which lave been expressed in favour of or against the revival of the system; they may be shortly summed up by stating, that those. who approve of it eontend that during its continuanee our fisheries progressively inproved, and that by the abrupt with. drawal of that cueouragement, they have deelined and beeome depressed in their eondition; while those who disapprove of the system say, that eapital was not supplied througli the mediun of the bounties, but that they operated merely as preminuns on the result of the very small portion of eapital then enbarked in the trade, but dicl not tend to inerease the eapital so employed. To the existing state of the fisheries, and the value of eneournging them as an industrial resouree, I now have to direet your attention. At the present period of clearth and seareity, when we are eompelled by neeessity to seek for every available mode of subsistenee for our famishing poor, it is justly a matter of surprise that they have not been more looked to as a souree for providing food of a eleap and nutritious eharneter. It las been remarked that, during the past year, the supply of fish on all oulr eoasts was mueh more abnndant than it has been for many years, and the weather has not proved unfavourable for their eapture.

"In the year 1782" (writes Mr. Knox), "when the Western Highlands of Seotland suffered so mneh from famine, the annual anrival of the herrings had never been known to fail eompletely till that remarkable year, when those little visitors scemed to eonspire with the sensons in order to rouse the. notiee of the Government towards those distant shores. While the elements kept back or destroyed the regnlar produee of the carth, the hernings abandoned their well-known ground, di- 
reeted their eourse towards the Irish Chanmel, or stopped there after their annual progress round the Land's-end; and whenee the Highlandei's, not being provided with proper vessels, were unable to follow them. But this was not all: whilst the people were deprived of grain, roots, milk, vegetables, and herrings (their usial food in good seasons), an almost uninterrupted sueeession of storms, sueh as had not happened within the me. mory of man, prevented theru from attempting the white fishery; neither, had the weather been moderate, eould they go out without the means of subsistenee: thus a double famine arose."

Comparing, then, the state of Ireland at the present moment (suffering heavily as she is under the dispensation of Providenee), with that of the Western Highlands in 1782, it will be admitted that we have not been as severely dealt with. Countless shoals of herrings abonnded on our eoasts and in our harbours, ereeks, and inlets, during the summer of the last year; and they have been sometimes absolutely used as manure for the ground for want of salt to preserve them. We have had no hurriennes to prevent ond fishermen from following the fisl, and yet we hear the ery of starvation in our maritime eounties-ay! and muel louder (as, for instanee, in the western part of the eounty of Cor'is) than in any other part of the eountry. Surely there ruist be something wrong in all this! Cannot the evil be arrested, and the progress of famine in some measure stayed, by providing means for our people to make nse of the food with whieh God has enriehed our seas; and while we seek to meet adversity, and to turn to proper aeeorut this great artiele of subsistenee, should we not endeavour to enltivate and permanently extend the fisheries as one of the best resourees of our national industry?

The quantity of fish whieh we use for our home consumption is very great, and I may say almost all the eured fish whieh we eonsume is imported from Seotland, to whom we have loug been steady and well-paying eustomers. Of this some idea may be formed, when 1 tell you that the supply of herrings yearly furnished by Seotland to us is very nearly equal to that whieh she exports to the rest of the world besides. From April, 1844, to 1845 , she sent us eured herrings to the extent of 120,293 barrels, many of the eontents of whieh were probably taken from our own seas, eured by her, and sold to us. Seotland, not blessed with the same advantages whieh we possess in soil or climate, derives a large revenue frou the industrious proseention of her fisheries; while Ireland, with land, and good land too, in waste, eapable of raising grain in abundanee, and 
having fisheries just as produetive, if not more so, negleet them, and suffer them to be used for the enriehing of others.

Are the fisheries properly pertaining to Seotland more abundant than our's? Yes, beeause their industry is greater. Are their harbours, more than our's, safe and aeeessible asylums for the refuge of their fishing eraft? Yes, beeause, naturally inferior, they have been made industrially superior to our's by the eonstruetion of piers and harbours of refuge. Is there a defieieney in labour to work the fisheries advantageously? The Ceusus, I apprehend, will answer, No. Or, again, is the sueeess of the Seoteh fisheries, as eompared with our own, to be attributed to any Govermment aid extended to them? I would say not; for, with the exeeption of the mere superintendenee of the Fishery Board, and a small distribution in the way of grants to fishermen for repairing their boats, the fisheries liave to depend on the industry of those engaged in the pursnit. What, then, is the true enuse of the depressed state of our Irish fisheries?

To the eonsideration of this question I shall now apply myself, and I liope to be enabled to shew that Irishmen possess means within themselves to plaee their fisheries upon a firm and eomprehensive basis, and to make them, like those of Seotland, a souree of abundant wealth.

Our fisheries (at least for my present purpose) may be eonveniently divided thus :

Our In-shore Fishery;

The Deep-Sea Fishery;

The Salmon Fishery ; and

The Oyster and Lobster Fisheries.

To the two former (as being the main sourees from whieh we may expeet to derive wealth by the proseention of them) I would more immediately eall your attention this evening.

The In-shore Fishery is that from which we reeeive the general supply of fiesh fish for lome eonsumption, and is ehiefly earried on in smaeks, wherries, and hookers, from five to twenty tons burden, and in smaller boats and yawls. In the more remote fishing distriets, with sone exeeptions, the eharacter of the fisherman partakes of that of neither sailor nor fisherman; in most instanees, properly speaking, he is an agrieultural labourer, following fishing more as a temporary resouree than as a trade. It may be, that the general proprietorship of land, even among the more humble of onr population, has strengthened the inlabitants of our maritime distriets in this partieular, and may have exereised an inflnenee on the regular and profitable proseeution of this branch of onr industry. The absenee of a steady daily market for the supply has tended 
materially to originate this mischief; for the fisherman, uneheered by the hope of being enabled to dispose of the produce of his labour, becomes indolent and apathetic in the pursuit of fishing, and naturally seeks in other occupations a more certain return for his industry. Besides, if he does succecd in taking a large quantity of fish, he has neither the means nor the facility to transport it to the more inland towns, where he would be certain of disposing of it; and cven those who purchase fish (the kedgers, as they are ealled on the western coast) are not enabled to bring it from remote districts soon enough to market, or in a sufficiently fresh condition to ensure a renumerative price. Again, the fishcrman, generally speaking, is totally ignorant of the art of cuing; and when the supply is greater. than the demand, he has no capital to purchase salt to preserve it; and mayhap if he had, it is not to be procured in his locality. This, combined with a want of the knowledge of curing, and the absence of a stendy demand, drives him, as I said before, to other sources of employment; and steadiness of demand, amongst a population who are not wealthy, eannot be expected for an article of comparative luxury, such as fresh fish, more partienlarly amongst the portion of the inland population, subject as hitherto to existing difficultics of supply. But these observations, so far as regards the sale of fresh fish, only apply wherc there are no markets, and where the faeility of carrying it to market does not exist. Wherever these two great desiderata are supplied, proportionate sucecss must attend the fisheries, and stimulate the energies and entcrprise of those engaged in them.

The fishing establishment at Dunnore is an interesting proof of the truth of this. In the year $1840 \mathrm{ML}$. Strangman of Waterford, with one or two other indivichals, associated in the purchase of two fishing vessels, of about thirty-five tons burden, and brought over some experieneed men from the southern const of England to earry on the trawl-fishing on that coast. Duninore possesses a most excellent and commodious harbour, from whenee Waterford is but distant twelve miles, and from thenee first-class steamers start weckly for the principal. English ports. A short experience proved to $\mathrm{Mr}$. Strangman how valuable the fisheries were on the coasts adjacent to Dummore, and he was enabled to shew a retum of twenty per cent. upon the capital expended. This soon induced others to follow his example; and upon my visiting Dummore in the early part of last year, I found twelve vessels of from thirty-five to forty tons permanently engaged in the decp-sea trawling:

A regular supply soon rencrited an increased demand; 
and fish-dealers for the English market soon established themselves in Waterford. They purehase the fish readily from the boats, paek it in iee, and, having faeility of transit by the stemmers, send it to London, Liverpool, and Bristol. The men oeeupied in these vessels reeeive a share in the produee eaught (being the only true means of eneouraging steacly industry), and thus, meeting with a eertain demand upon their arrival from fishing, they are natiaally led on to inereased excrtion and enterprize. Mr. Strangman told me that the English dealers pay for turbot $10 d$. to $1 s$. per lb., and for sole $4 d$. to $5 d$. To steady markets and great faeility of transit thereto may be attributed these ligh priees: and it is truly painful to contrast the pleasing effeets produeed by these means with those observable in the more remote distriets, where sueh advantages clo not exist. In Crookhaven, on the sonth-western eoast of Cork, I have often purehased a large-sized turbot for 1 s., and soles for $2 d$. and $3 d$. eaeh, whieh, it is obvious, would never have been disposed off at sueh a priee if the fishermen eould have reekoned with any degree of eertainty on a more remunerative market.

With these few remarks on the state of our In-shore Fisheries, I now pass to eonsider the state of the Deep-Sea Fisheries, whieh may indeed be said to be altogether negleeted and untried; not that there is any laek of a due appreeiation of their importanee and productiveness, but that the want of eapital among those who are aware of their value prevents them from being proseeuted and made a souree of abundant wealth. The deep-sea banks (at least so many of them as have been diseovered) lie generally at a distanee of some thirty or forty miles from the shore, and abound with quantities of cod, ling, and haddoek, the right to fish whieh banks is in ourselves; but in the ill-found, crazy, and undeeked boats of our fishermen, it would be useless, as well as hazarclous, to attempt this fishing, and the eost of a ressel suitable for earying it on is a sum absolntely unattainable to them. With fishing gear eomplete it would amount to at least $£ 650$; and thus, fiom the absenee of eapital engaged, the deep-sea fisheries afford us little, if any, of their valuable produee; but we must not forget that, with vessels equally eostly, the Dutel ("witlout one timber-tree growing in their eountry") for centuries have been in the habit of adding sueh a large amount to the wealth of their state.

Upon the one liand, then, we have our In-shore Fisheries carried on to a very limited extent, and the supply therefrom uneertain, prineipally in consequence of the want of markets and means of conreyanee to them; added to which there is a 
lamentable ignoranee of the euring arit, and an utter absence of the means of earrying it on: and on the other hand we find our extensive deep-sea banks are left untried and uneultivated, in eonsequence of the want of eapital to supply vessels of an adequate size for the proseeution of that fishery. How are these evils to be remedied-by what 'or by whose instrumentality? Some urge the neeessity of Governinent interferenee, and even go so far as to eall for a revival of the bounty system; others look to the establishment of joint-stoek eompanies, who would supply boats, as the best means to effeet improvement in the fisheries; while to the eombimation and assoeiation of eapital by a few individuals attaehed by local interest to the fishing station (whieh maÿ be legally ealled a loeal partnership), do others look for any eeitain sueeess.

And first, with respect to Govermment interferenee, a step, and a most wise and salutary one, has been already taken by the Commissioners of Fisheries, that is, the Board of Works, who, finding the great evils whieh arose on the western eoast from a want of a steady daily demand, have established three stations for the purchase and euring of fish. The plaees (where I may say by this time their operations are already eommeneed) are Roundstone, Belmullet, and Killybegs. Salt has been stored, eompetent eurers have been employed, the neeessary means and applianees for euring ereeted, and the Government, through its offieers, intend for a limited period to beeome the purehasers of fish, but only in the event of there being no other purehasers in the market, and then at a fixed and fair piee; thus, with the smallest possible amount of interferenee, to ereate a market for the fisherman, and, by example, stimulate his industry and arouse his energies. A small supply of lines and hooks will be deposited at each station; every faeility will be afforded to our native fishermen to learn euring; and the fish, when eured, paeked, and barrelled, will be sold; and, by showing that a remunerative priee ean be obtained, men of enterprise, eombining in a spirit of mutual eonfidenee, may be indueed to follow the example thus set by the Government. As far as I am enabled to offer an opinion on the subjeet, I look to this move as one of the surest steps to the ultimate development of the fisheries as a trade.

In the establishment of joint-stoek eompanies for fishing, and for providing boats for fishermen for deep-sea purposes, some look with eonfidenee for an effeetive result; but I am bound to say, at the same time, that sueeess has not attended the many attempts whieh have already been made for that purpose. I am fully aware that now-a-days eompany-making is unpopular, and, perhaps, the reason may be that parliamentary 
exemption from liability has rendered shareholders less careful of the general eoncern than in ordinary partnerships; for I am persuaded that mutual eonfidence is the great source, not only of private mereantile aggrandizement, but of national prosperity:

" Bona fides reipublicæ stabilitas."

The clubbing together of fishermer themselves for the purchase of vessels for the earrying on of the fisheries, as is generally adopted on the coasts of England and Scotland, is prononnced by many to be the best organization for fishing purposes; for those who subscribe their eapital are at once proprietors and fishermen, and are praetically engaged in the endeavour to make it a remunerative investment, by working their own vessels; and thus the great expense which the management of a company would necessarily entail is by this plan saved. There can be no doubt that if capital could be extensively combined among onr fishermen, it would reasonably produce the best results; but until it be fortheoming in this way, we should not eondemn efforts to obtain it through the medium of joint-stock capital. These undertalings lave latterly undergone sueh a depression in public esteem, that it is not at all improbable that private enterprise may resume its old legitimate form of mutual responsibility and co-operation, and that we may yet experience on our shores all the benefit of extensive private assoeiation. Attempts are now maling to organize companies, some for supplying fishing-boats and fishing, and others for merely euring and purehasing fish. The latter appears to me to be the safer plan, for capital may be thrns managed with more scrutiny than when afloat ( $I$ mean in the purchase of vessels or in the occupation of fishing); bnt since capitalists in both eountries have become habitnated to the employment of their eapital under Acts of Parliament in joint-stoeks, we must naturally look to those operations of commeree in the firstinstance for development of such resources as we at present possess.

Having thus brought before your view some frets eonnected with the earlier value of our Irish fisheries, and the legislation under which they have been protected and encouraged, the state of our In-sliore and Deep-Sea Fisheries, and the leading causes of their depressed condition-and having endeavoured to place before the Society, in a very general way, the most praetical plans which have been snggested for their improvement, let us for a moment reflect on the great and inestimable value which would arise if we were enabled to place them in 
anytting like a working eondition as a trade. "Mines" (says Raynal) "ean be exliansted, and the fisheries never are. Gold is not reprodueed, but the fish are so ineessantly; and he (to use Dr. Franklin's words) that puts seed into the ground reaps fifty-fold, but he that puts a line into the sea and pulls out a fish pulls out a pieee of silver." These mines, then, are around our eoast, for which we are not ealled to pay for the privilege of working. We have abundant labour, and were eapital fortheoming to forward. our fisheries, our eoast populationmen, women, and elildren-would soon find oeeupation and employment of a profitable and permanent kind: the meu in building boats and in fishing-the women and ehildren in the manufacture of nets, and in the several stages of the euring proeess. Seotland does all this; she sends her produee to the Europenn and Indian markets as well as to ns. Her exports last year in herrings alone, to plaees in and ont of Eirope, were 176,080 barrels, produeing a large and important return, and employing a great number of fishermen and their families, cooper's and ropemakers, ships and seamen, to eonvey the salt for euring. Spain, too, I find, has reeently sent to Seotland for her lienings; and, spite of duties amounting almost to a probibition, they have found their way to the heart of Franee. Is it not, then, justly a matter of wonder and astonishument that Ireland, with her eoast supplied as abundantly, if not more so, than any mation in the world, with equal faeilities witl Seotland for shelter, eonveyanee, and opportunities for export, should not only snffer so great a souree of wealth to be uneulvated, but should weaken the right hand of her maritime strength, by allowing the fishermen to be unemployed and ineapable of serving with effieieney in our navy when oeension should require their serviees.

Before any thing, in my liumble judgment, ean be done for the permanent improvement of the fisheries, and for the establishing of an export trade, we must supply our fishing eommunities with materials for earrying it on. And, first of all, we must lave piers and harbours of refuge along onr eoasts. Already there has been legislation upon this snbjeet; and a Statute, whieh I before eursorily allucled to, was passed last session, and a sum of $£ 50,000$ was granted for the promotion and extension of our fisheries, by giving grants of publie money for the eoustruetion of piers and harbours. As I an informed, the provisions of this Aet are in eourse of extension to no less than thirty-six plaees in Ireland; and I an given to understand, that the applieations to the Board of $W$ orks for erecting piers, \&e., wcre much morc numerous than could be 


\section{Ixxiii}

supplied by a grant of twice the amount given by the Statnte, evidencing in no small degree that there is a desire to encourage and proteet the interests of the fisheries, at all events in this particular. If they (the fisheries) be camied out in connexion with the piers and harbours, as has been indicated, these, at least, eannot be called unproductive works.

The next step should be to erect euring-houses, and stores for salt. For, however a luxurions market like that of London or Dublin may consume the supplies of fresh fish hitherto obtained, it is to the great national consumption of eured provisions we must look for sueh a market as shall ereate what may be truly called national prosperity. This desirable object of establishing eming-houses may be well effected by the same machinery as that provided by the Piers and Harbours' Act, namely, by the co-operation of parties locally interested witl the Government. These great and essential materials, namely, piers and curing-houses, being extensively supplied, we may then look eonfidently for the gradual embarking of capital for the building boats, \&c., supplied as it must be either through local resources, or through the medium of joint-stock capital.

Loans, in kind, of lines, hooks, and other necessary gear, may be established with beneficial results. How often is the poor fisherman umable to procure the implements of his trade, umless at a high price, from the eountry dealer, and then of an inferior eharacter. The resident gentry in the neighbourhood of the fishing station may aid in the management of the loans, whieh would have the good effect of making them acquainted with the characters of the fishermen, and enable them to discriminate between the industrious and the indolent.

Light carriagcs or carts may be established, throngh private or other enterprise, for the conveyanee of fresh fish from the distant and more remote districts to the inland towns, which would no doubt be a most remunerative speculation. And here I would say, that the various relief committees and associations thronghont the country may do well to adopt this snggestion. The guardians of the poor, too, may profit by it; and workhouses, from their superior arrangement, while they might obtain what might otherwise be considered objects of luxury (that is, fiesh fish), might repay the supply by manufacturing nets and other engines for the produetion of their sustenanee. Fish is brouglit by carriage conveyance from the coast of Franee to the interior ; and the ressels engnged in the fishery at Boulogne, Dieppe, \&e., land their produce, to be transported with rapidity and dispatch to Paris and the intermediate towns. The establishment of railways in that country 
will soon render this mode of conveyance unnecessary, but until railways extend in Ireland, and afford increased accommodation of transit, shonld we not make use of those modes which have been found to answer so well in France?

Our deep-sea fishing banks, too, should be surveyed by government, as well with the view of ascertaining their exact position, as of recording their productiveness.*

During the past year some gentlemen with whom I connected myself sought to organize a company for supplying fishing-boats, and for fishing generally. We presented a memorial to the late government for a vessel to survey the great Nymph Bank, and a revenue cruiser was at once placed at our disposal; but not having received public support, we were, with much regret, unavoidably prevented from taking advantage of this liberal offer.

The expense of providing gear would have been very considerable (more than those who organized the project felt themselves called upon to incur), and it was even questioned by practical men whether the survey conld have been effectively carried on by one vessel, and more particularly as the time was limited for her occupation in our service. I believe, also, that the value of any survey made by private individuals would not be recognized by the public as authentic, aud that to be really useful it should be conducted by Government, through the medium of its own officers, aided by experienced fishermen, as well as by men of science. A report formed on a survey of this kind would be most valuable, particularly to those anxious to embark in the fishery of the deep seas, and a knowledge of the position and of the resources of the banks would, I have no doubt, tend to increase the number of vessels of that size sufficient and capable for promoting those fisheries.

If we were in the condition of those enterprising Dutchmen, who, without the aid of joint-stock companies, and Joint-Stock Company Acts, relying on the mutinal honesty of merchants, fished the Dogger Bank by private capital, we might have no difficulty in seeing our way to the realization of all the wealth which Proviclence has manifestly placed in the hancls of men who can mutually confide in one another. As it is, habituated as we have been, for two generations, to the protection of parliamentary associations, it is hardly to be expected that private enterprise and individual responsibility could come

*Mr. Strangman, of Waterford, told me that he, as well as others, would have embarked capital in providing vessels for carrying on the deep-sea fisheries of the Nymph Bank, but that they wore deterred fiom so doing, in consequence of the expense which a preliminary survey of its position and productions wonld entail. 
forward in aid of long, laabitual negglect; but a great public Society, incorporated for thic promotion of national industry, may at least hold out a hand of encouragement alike to those who have becn accustomed to excmpted liability, as to those who rely on the great mereantile inclustry which had created the commercial prospcrity of Holland, of England, of Amcrica; and may shew to all men of cnterprise the means whoreby they may increasc their wealth, and promotc common prosperity. And not only conld this Socicty, by taking up the lisherics as an industrial resouree (a mariue husbandry justly within their charter), stimulate the cuterprise of capitalists of all denominations, but, in a clegrce only secondary to the seicntific operations on the dry surface of the soil, extend the kingdom of seicnee into the depths of the sca, hitherto deemed inacecssible, and, by completing the survcy of the bottom of the occan, curieh the knowledgc of marine zoology, gcology, and botany. If such surveys, seientifically asecrtained, and reduced, as they easily might bc, to modes of expression which humble men could understand, werc made aceessible to the members of our fishing community, there can be no doubt that capital would be applied in a mueh more remuncrative mamner than at prescut, when the fishcrmen can only depond on empyrical observations for the place, season, or quality of bait, se., nccessary to carry on thcir opcrations. Thesc, howcrcr, arc remote considerations, depcnding on the applieation of cultivated minds to scicntifie inquiry through long periods of observation; but, in the mean time, praetical experience and mature consideration of what is alieady known upon the subject may enable me humbly to suggest to your Soeiety sone means within your inmediate ability to adopt, by which these incstimable resources may be made morc immediatcly productive.

I would suggest, thercfore, that in your museum, wherc you have annanged the modcls of thosc instruments most efficicut for the production of the fruits of the dry soil, you also should give a place to those other implements not less needful, by which food and wealth may be drawn fiom the soil covered by the sea. Amongst such models, one which I conccive in the prescnt state of our fisheries' interests may be among the most inmediately uscful, is that eart which I have already spoken of for the transit of fresh fish from the eoast to the market, a model of which, to be constrneted from the best cxamples of such conveyances, I shall have the honour to submit to the Society, and to pray of them to place in their industrial collection, as a nuclcus, however inadequate, for a future marine industrial misenm. 
